\title{
W KWESTII KONTAKTÓW SLOWIAŃSKO-SKANDYNAWSKICH WE WCZESNYM ŚREDNIOWIECZU. WOLIŃSKIE OSELKI Z METALOWYMI ZAWIESZKAMI
}

\author{
SLAVIC AND SCANDINAVIAN CONTACTS IN THE EARLY MIDDLE AGES. \\ WHETSTONES WITH FERRULES FROM WOLIN ISLAND - \\ LIST OF FIGURES
}

\begin{abstract}
The article presents the origin and function of phyllite whetstones with ferrules. Some researchers trace them back to the inhabitants of Scandinavia. However, in the light of the available data and new findings, the whetstones should be attributed to Slavic craftsmen who may have operated in Wolin island. These whetstones were status symbols rather than daily use objects.
\end{abstract}

Keywords: Scandinavia, Slavic domain, Wolin island, whetstones with ferrules.

Wśród licznych zagadnień i pozostałości kultury materialnej, które znalazły się w polu zainteresowania Władysława Łosińskiego, były także wyroby kamienne, w tym osełki. Badacz ten poświęcił im stosowny passus w artykule na temat kontaktów handlowych Słowiańszczyzny Nadbałtyckiej ze Skandynawią (Łosiński 1997, s. 76). W tekście poruszone zostały głównie aspekty surowcowe i problem importu osełek z lupku fyllitowego pochodzenia norweskiego. W literaturze dominują dwa przeciwstawne poglądy, wedle których surowiec do ich wyrobu pochodzić miał ze Skandynawii lub z południa Polski z Sudetów (por. dyskusję referuje Kara 2006; a ostatnio Szydłowski 2011; 2013; Lisowska 2013, s. 216-220). Jednakże to nie to zagadnienie będzie motywem przewodnim niniejszego tekstu. Osełki były $\mathrm{w}$ średniowieczu przedmiotami pierwszej potrzeby, służyły bowiem do ostrzenia przedmiotów tnących, kłujących i innych ostro zakończonych, a także do czyszczenia powierzchni z metalu, rogu, kości, drewna i kamienia. Dbano więc, aby osełkę mieć zawsze przy sobie. Istniały na to różne sposoby. Można było umieścić

* ORCID: 0000-0002-3272-3444; Instytut Archeologii i Etnologii PAN - Ośrodek Archeologii Średniowiecza Krajów Nadbałtyckich, ul. Kuśnierska 12/12a, 70-536 Szczecin, e-mail: andrzej.janowski@wp.pl. 
ją w woreczku lub innym pokrowcu przytroczonym do pasa- albo zawiesić bezpośrednio na nim (por. Lisowska 2013, s. 109). W tym celu najczęściej na jednym z końców osełki wykonywano otwór, przez który przewlekano rzemień lub w którym umieszczano metalowy pierścień, a całość zawieszano przy pasie. Oprócz tego istnieje niewielka grupa osełek, które zaopatrzono w specjalne metalowe okucia zwieńczone uszkiem. I to właśnie te charakterystyczne metalowe uchwyty, a nie surowiec będą osią mojej narracji.

Zaopatrywanie osełek w metalowe okucia zwróciło uwagę badaczy, było bowiem biegunowo odległe od materiałów znanych z ziem słowiańskich. Stało się też pożywką dla szeregu teorii wyjaśniających ich funkcję, objaśniających zdobnictwo oraz proweniencję. Przypomnę zatem, że dotychczasowa dyskusja toczyła się, opierając się na materiale, który stanowiły zaledwie cztery przedmioty.

Pierwszym z nich była kompletnie zachowana osełka ${ }^{1}$ (ryc. 1). Przedmiot ten wielokrotnie publikowano (m.in. Lamm 1987, Fig. 9; Stanisławski, Filipowiak 2013, il. 22), przemilczając jednak informacje o miejscu odkrycia oraz bliższe dane o niej samej. Według księgi inwentarzowej osełka została znaleziona w 1975 r. około 100 m na północ od Srebrnego Wzgórza w Wolinie w trakcie pozyskiwania ziemi na budowę nasypu kolejowego. Zachowany w całości zabytek ma długość 98,62 mm, a 22,26 mm przypada na wieńczący go uchwyt. Osełka ma czworoboczny przekrój o zmiennych wymiarach (przy okuciu $9,97 \times 4,35 \mathrm{~mm}$; na przeciwległym końcu $11,03 \times 6,10 \mathrm{~mm}$ ) i waży $11,8 \mathrm{~g}$. Okucie osadzono na węższym końcu, a na obu jego szerszych bokach czytelny jest wypukły ornament w postaci dwóch kropek rozdzielonych pionową linią. Płaszczyzny węższych boków nie są zdobione. Okucie wykonano z prawie czystej cyny - 98,52\%. Stop zawiera ponadto niewielkie ilości innych pierwiastków/zanieczyszczeń: As - 0,33\%, Si $0,31 \%, \mathrm{Fe}-0,28 \%, \mathrm{Cu}-0,28 \%, \mathrm{Al}-0,15 \%, \mathrm{~Pb}-0,13 \%{ }^{2}$.

Oprócz kompletnej osełki argumentami w debacie były też znalezione w Wolinie uchwyt do osełki (?) oraz forma do wykonywania takich przedmiotów. Pierwszy przedmiot odkryto w 1974 r. w wykopie 6, ar $1660^{3}$ (ryc. 2). Zabytek zebrano w warstwie XIV w jamie, którą datować można na 2. połowę IX-początek X wieku. Okucie wykonano z cyny $(98,79 \%)$ z niewielką domieszką innych składników: $\mathrm{Pb}-0,49 \%, \mathrm{Si}-0,27 \%, \mathrm{Cu}-0,20 \%$, As - 0,07\%, Ni - 0,07\%, Cr - 0,06\%, Fe $-0,05 \%$. Przedmiot ma wysokość $36,6 \mathrm{~mm}$ i zakończony jest owalnym uszkiem o wymiarach wewn. $4,2 \times 2,8 \mathrm{~mm}$. Dzwon ma w przekroju kształt czworoboku o bokach długości 11,5 i 9,8 mm. Jego wysokość wynosi $23 \mathrm{~mm}$, a głębokość

\footnotetext{
${ }^{1} \mathrm{Nr}$ inw. polowego 2/75.

${ }^{2}$ Analizę składu chemicznego wykonało w 2016 r. Laboratorium Bio- i Archeometrii IAE PAN w Warszawie (analiza nr CL19482).

${ }^{3} \mathrm{Nr}$ inw. polowego $5778 / 74$.

${ }^{4}$ Analizę składu chemicznego wykonało w 2017 r. Laboratorium Bio- i Archeometrii IAE PAN w Warszawie (analiza nr CL19867). W jednej ze starszych prac podano, że zabytek wykonano ze srebra. Błędnie odnotowano też jego numer 1311/71 (por. Stanisławski 2000b).
} 

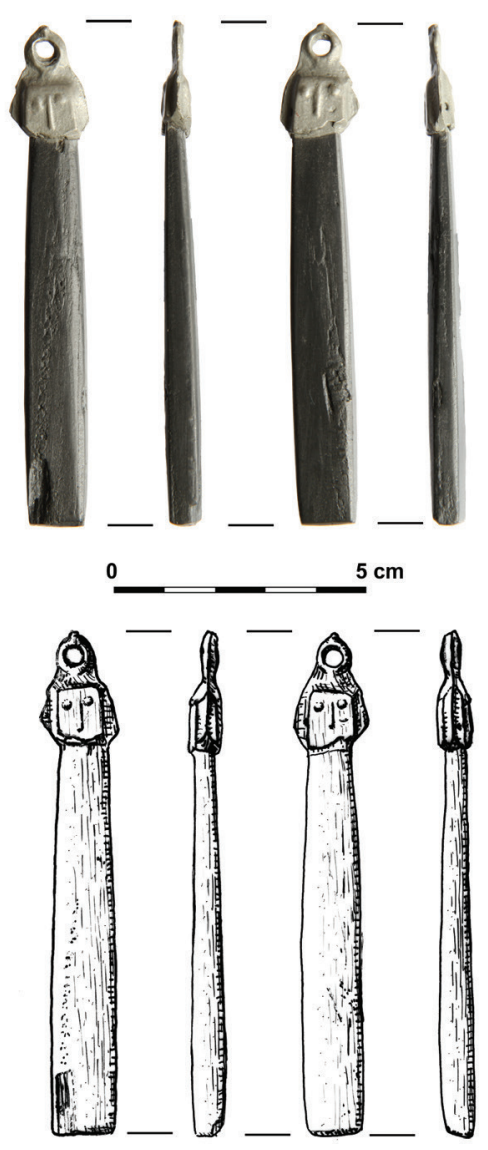

Ryc. 1. Wolin. Osełka nr inw. 2/75 (rys. K. Zielińska, fot. A. Janowski)

19,9 mm. Przedmiot waży 12,6 g. W tym przypadku wypukłym ornamentem zdobione są wszystkie boki. Na jednym widoczne jest wyobrażenie zwierzęcia ${ }^{5}$ (pies? - por. Filipowiak 1986, s. 17; 1991, s. 18, Fig. 21), a na trzech pozostałych widać mocno wydłużone romby, które zdaniem części badaczy są stylizowanym przedstawieniem twarzy (por. Filipowiak 1986, s. 17; 1991, s. 18, Fig. 21; 1993, s. 30-31; ryc. 15). Jeden $\mathrm{z}$ nich, położony na stronie przeciwległej wyobrażeniu zwierzęcia, otoczony jest perełkowym otokiem. Na bocznych płaszczyznach czytelne są wyraźnie szwy odlewnicze, a ich przesunięcie wskazuje na nieprecyzyjne wykonanie formy lub jej spasowanie przed wlaniem metalu. 2000b).

${ }^{5}$ Niektórzy autorzy pisali nawet, iż cały przedmiot ma kształt psiej głowy (por. Stanisławski 
W rok po odkryciu uchwytu w stosunkowo niewielkiej odległości od niego znaleziono kamienną formę odlewniczą, która mogła służyć do produkcji podobnych przedmiotów (ryc. 3). W starszej literaturze znaleźć można informację, że miejscem jej odkrycia było Srebrne Wzgórze (por. Stanisławski, Filipowiak 2013, il. 43). Zapis w księdze inwentarzowej ${ }^{6}$ nie pozostawia wątpliwości, że odkrycia dokonano jednak na Starym Mieście 21.07.1975 r. w wykopie budowlanym zlokalizowanym około $50 \mathrm{~m}$ na północny zachód od wykopu archeologicznego $\mathrm{nr} 6$ (ar 1709) w warstwie kulturowej $j_{2}$ prawdopodobnie z XI wieku. Zabytek wykonany jest ze steatytu (Filipowiak 1991, s. 18, Fig. 22) 7 i w rzucie z góry ma kształt zbliżony do prostokąta o długości 48,26 mm i szerokości 32,3-35 mm. W przekroju natomiast ma kształt przeciętego na pół ośmioboku. Grubość formy wynosi $18 \mathrm{~mm}$. Na górnym boku widoczny jest kanał wlewowy, a poniżej zarys odlewu w kształcie trapezu zakończonego półokrągło i zwieńczonego uszkiem (dług. 29 $\mathrm{mm}$, szer. podstawy $13 \mathrm{~mm}$, szer. zwieńczenia $8,4 \mathrm{~mm}$ ). Od dołu forma jest otwarta. Wykonywany $\mathrm{w}$ formie przedmiot był zdobiony. W dnie formy wyryty jest ornament, który w postaci wypukłego negatywu widoczny był po odlaniu na jednym z szerszych boków okucia. Ma on postać zwierzęcia z ogonem oraz głową o wydłużonym pysku i z dwoma rogami lub uszami ${ }^{8}$.

Ostatnim przedmiotem, który wiązano z omawianą problematyką, jest również forma odlewnicza, tyle- że znaleziona w Szczecinie (ryc. 4). Wykonany ze steatytu ${ }^{9}$ zabytek ma w rzucie poziomym kształt trapezu o długości $71 \mathrm{~mm}$ i szerokości $42-52 \mathrm{~mm}$. W rzucie bocznym jest półokrągły, a jego grubość wynosi $34 \mathrm{~mm}$. Przedmiot jest starannie wygładzony. Na płaskiej powierzchni w jej górnej części czytelne są negatywy pięciu „haczyków”, a w dolnej, szerszej partii dwa negatywy przedmiotów zdobionych wizerunkami twarzy i zaopatrzonych w wydatne półokrągłe uszko. Większy miał średnicę 17-23 mm, a mniejszy 12-18 mm. W każdym z negatywów widoczne są dwie połówki i jedna cała twarz. Mają one wydłużony kształt. W górnej części zaznaczono duże owalne oczy, wydatny nos oraz brwi. Niżej otwarte usta w kształcie owalu oraz brodę. Obecność tego ostatniego detalu pozwala przypuszczać, że są to twarze mężczyzn. Twarze otacza bordiura z taśm utworzonych przed dwie równoległe linie i z przestrzenią pomiędzy podzieloną pionowymi kreskami na mniejsze odcinki. W przypadku obu negatywów wizerunki twarzy są bardzo wyraźne i zakładając, że druga połowa formy była symetryczna, to przedmioty w niej odlewane zdobione były wizerunkami czterech twarzy.

\footnotetext{
${ }^{6}$ Inwentarz zabytków wykop 6, ar 1709, zeszyt IV - nr inw. polowego 1609/75. W literaturze błędnie podawano $\mathrm{nr}$ inw. polowego 1809/75.

${ }^{7}$ Niezależna analiza przeprowadzona w 2017 r. przez dr. Marcina Szydłowskiego z Katedry Archeologii Uniwersytetu Szczecińskiego wstępnie potwierdziła tę identyfikację.

${ }^{8}$ Zapewne przez analogie do opisanego wcześniej okucia niektórzy autorzy opisali formę jako przeznaczoną do odlewania zawieszek w kształcie psiej głowy (por. Stanisławski 2000a).

${ }^{9} \mathrm{Za}$ informacje na temat surowca serdecznie dziękuję Pani dr Annie Bogumile Kowalskiej z Instytutu Archeologii i Etnologii PAN w Szczecinie.
} 


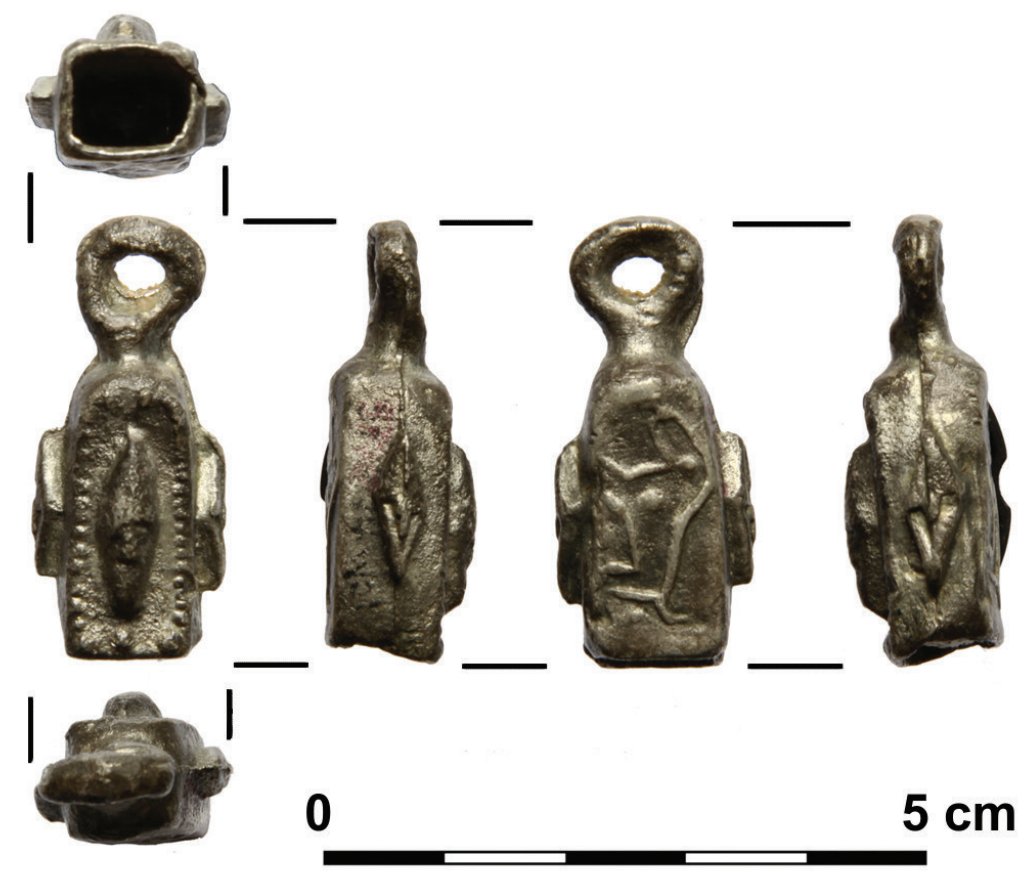

Ryc. 2. Wolin. Zawieszka osełki nr inw. 5778/74 (fot. A. Janowski)

Formę znaleziono pod koniec XIX w. na terenie szczecińskiego Podzamcza podczas inwestycji prowadzonych w rejonie ulic: Schuhstrasse, Baumstrasse i Fischerstrasse, czyli dzisiejszych ulic: Szewska, Kłodna i Rybaki (por. Kowalówka 2012, tu starsza literatura).

Bliższe przyjrzenie się czterem opisanym zabytkom nie pozostawia wątpliwości, że tylko jeden z nich - zawieszka z wykopu 6/1660 - posiada kontekst, który umożliwia precyzyjniejsze datowanie. W przypadku pozostałych zdani jesteśmy na mniej lub bardziej prawomocne hipotezy. Mimo to powstało kilka koncepcji, czym były i do czego służyły te przedmioty. Najbardziej wyważony w swoich opiniach był Władysław Filipowiak. Omawiane przedmioty pojawiły się jako ilustracja wywodów w kilku artykułach tego autora poświęconych wierzeniom przedchrześcijańskim na Pomorzu. Zdobienie na szerszych bokach kompletnej osełki przypomina nieco bardzo schematyczny rysunek ludzkiej twarzy ograniczony jedynie do zarysowania oczu oraz nosa. W związku z powyższym autor ten pisał o wyobrażeniach dwutwarzowych występujących na okuciach osełek w Wolinie, począwszy od IX-X wieku. Ludzkiej twarzy dopatrzył się on także na okuciu osełki znalezionym w 1974 r. (Filipowiak 1993, s. 30). Antropomorficzna interpretacja kształtów i wyobrażeń widocznych na okuciach i w formie odlewniczej cał- 
kowicie zdominowała późniejsze ustalenia i kierowała dyskusję w stronę rozważań nad ich apotropaicznym przeznaczeniem i wykorzystaniem w sferze kultowej. $\mathrm{Z}$ czasem zmieniła się jedynie identyfikacja obszaru, z którego pochodzić miał impuls do powstania takich przedmiotów. Do zagadnienia tego wrócę jeszcze niżej w tekście. Wydaje się, że dziś na zagadnienia te można ponownie spojrzeć w świetle nowych znalezisk.

Pierwszym jest kolejna zachowana w całości osełka z Wolina. Przedmiot znaleziono w 2013 r. w trakcie prac archeologicznych w porcie ${ }^{10}$ (ryc. 5). Niestety miejsce i okoliczności odkrycia pozwalają jedynie na przyjęcie ramowego datowania na X-XI wiek. Wymiary zabytku są bardzo zbliżone do opisanego wyżej długość $98,11 \mathrm{~mm}$, z czego 21,3 mm przypada na wieńczący go uchwyt. Osełka ma czworoboczny przekrój o zmiennych wymiarach (przy okuciu 9,95×4,75 mm; na przeciwległym końcu $13,11 \times 6,54 \mathrm{~mm}$ ) i waży 21,3 g. Prawie dwukrotnie większa masa osełki wynika $\mathrm{z}$ faktu, iż jest ona masywniejsza od omówionej wcześniej oraz z odmiennego składu chemicznego uchwytu, do którego wykonania użyto stopu cyny z ołowiem: $\mathrm{Sn}-55,3 \%$ i $\mathrm{Pb}-42,5 \%$. Stop zawiera ponadto niewielkie ilości innych pierwiastków: $\mathrm{Fe}-1,01 \%, \mathrm{Cu}-0,79 \%$, As - 0,21\%, $\mathrm{Al}-0,15 \%$, $\mathrm{Ni}-0,04 \%^{11}$. W tym przypadku ornamentowana jest tylko płaszczyzna jednego z szerszych boków. Tu również zastosowano ornament wypukły, ma on jednak postać sześciu kropek rozmieszczonych po trzy w dwóch poziomych rzędach. Trzy kropki (dwie u góry i centralna na dole) połączone są dwoma ukośnymi liniami w kształt litery V. Płaszczyzny węższych boków nie są zdobione.

Kolejnym prawie kompletnym zabytkiem z ziem polskich jest osełka znaleziona w 2008 r. w humusie na stanowisku 4 w Gieczu ${ }^{12}$ (Krysztofiak 2016, ryc. 25f). Jej długość całkowita wynosi $95 \mathrm{~mm}$, z których 11,2 mm przypada na okucie (ryc. 6). Niestety zły stan zachowania zwieńczenia uniemożliwia wypowiedzenie się na temat jego wyglądu. W tym przypadku nie posiadamy też informacji na temat surowca kamiennego oraz składu chemicznego okucia.

Oprócz omówionych wyżej z obszaru Słowiańszczyzny Zachodniej pochodzi przynajmniej jeszcze jeden zabytek $\mathrm{w}$ interesującym nas typie ${ }^{13}$. Jest nim osełka znaleziona w 1984 r. w wykopie VI w centralnej partii grodziska w Parchimiu -Löddigsee w południowo-zachodniej Meklemburgii (ryc. 7). Stanowisko to odkry-

\footnotetext{
${ }^{10} \mathrm{Nr}$ inw. polowego W3/2012/777/O. Miejsce prac archeologicznych znajduje się w strefie ochrony konserwatorskiej stanowiska $\mathrm{nr} 3$, jednak z perspektywy historycznej jest to północna część południowych przedmieść Wolina (stan. 2) i wpisuje się we wcześniejsze odkrycia reliktów nabrzeży por.Janowski 2013; 2014.

${ }^{11}$ Analizę składu chemicznego wykonało w 2016 r. Laboratorium Bio- i Archeometrii IAE PAN w Warszawie (analiza nr CL19483).

$12 \mathrm{Nr}$ inw. polowego GZ4 134/08.

${ }_{13}$ Już po zamknięciu prac nad tekstem ukazała się publikacja materiałów z grodziska w Szwerinie, a wśród nich metalowego okucia/uchwytu osełki datowanego na 2. tercję XI w. (Ruchhöft 2017, 97, Abb. 14).
} 


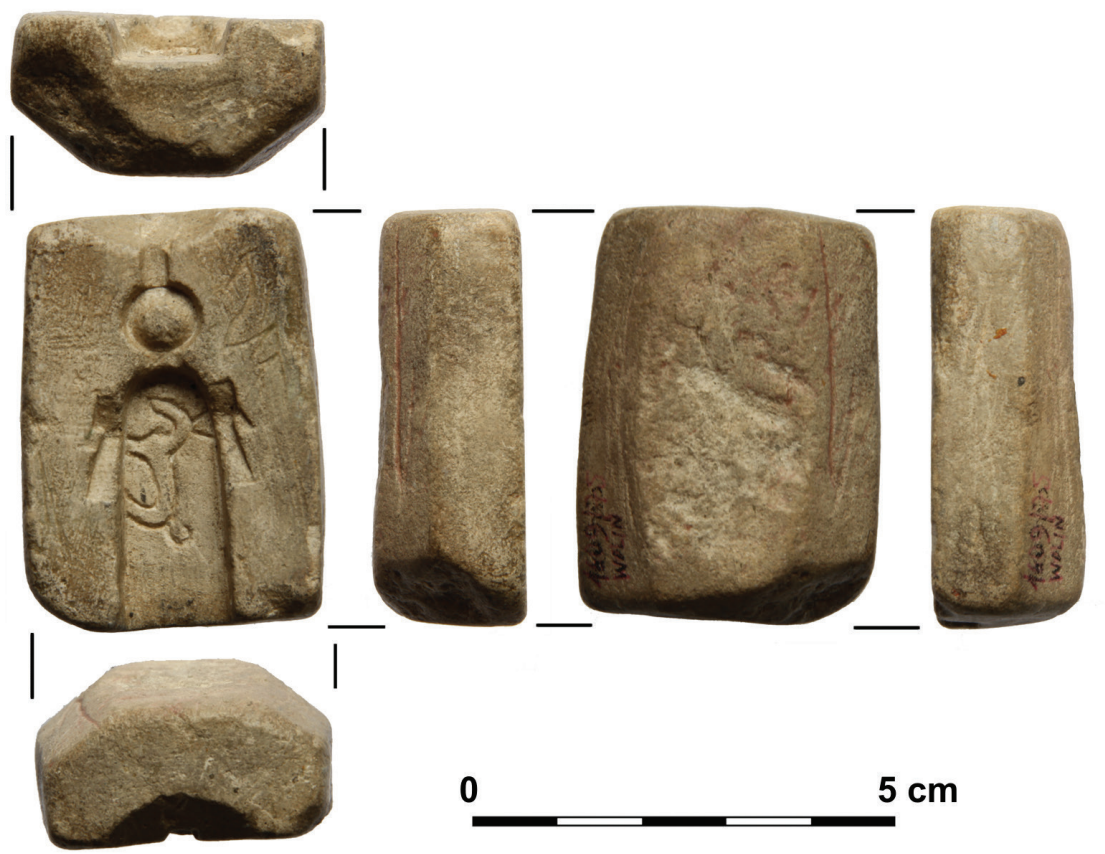

Ryc. 3. Wolin. Forma do odlewania zawieszek do osełek nr inw. 1609/75 (fot. A. Janowski)

te zostało przypadkowo $\mathrm{w}$ trakcie prac melioracyjnych $\mathrm{w} 1975 \mathrm{r}$. i prawie w całości przebadano je $\mathrm{w}$ ramach kampanii wykopaliskowych, które trwały z przerwami od 1981 do 1999 roku. Na grodzisku wyróżniono dwie fazy użytkowania przypadające na okres 1 . połowy XI -1 . połowy XII wieku. Zachowany fragment osełki z łupku zaopatrzono w okucie o charakterystycznym spłaszczonym kształcie. Według opisu w katalogu element ten wykonano $\mathrm{z}$ cyny ${ }^{14}$ i pierwotnie był on zdobiony ornamentem punktowym, o nieokreślonym dziś wyglądzie. Zachowany fragment ma długość około $33 \mathrm{~mm}$, z których około $20 \mathrm{~mm}$ przypada na okucie, które mierzy około $15-16 \mathrm{~mm}$ szerokości ${ }^{15}$. Zabytek waży $8,76 \mathrm{~g}$ (por. Paddenberg 2012, s. 58, Taf. 39.3934).

Porównanie omówionych przedmiotów pozwala na stwierdzenie bardzo bliskich relacji formalnych pomiędzy obydwoma osełkami z Wolina i okazem z Parchima -Löddigsee ${ }^{16}$. Forma, kształt, a nawet wymiary okuć są tu niemal identyczne, a różnice dotyczą jedynie ornamentyki. Nie ma wątpliwości, że u postaw powstania tych przedmiotów legła wspólna idea. Być może podobnie było w przypadku sa-

\footnotetext{
${ }^{14} \mathrm{~W}$ opracowaniu brak danych na temat składu chemicznego.

15 Wymiary na podstawie ryciny.

${ }^{16}$ Okucie osełki z Giecza jest zbyt słabo zachowane, by podjąć takie rozważania.
} 
mego okucia znalezionego w 1974 r., choć jego kształt, proporcje i głębokość (prawie dwukrotnie większa) są odmienne. Nie ma jednak wątpliwości, że przedmiot zwieńczony tym okuciem miał czworoboczny przekrój i stosunkowo niewielkie wymiary, co odpowiada kształtowi osełek fyllitowych. Dodatkowym argumentem mogą być w tym przypadku także cechy technologiczno-techniczne. W przypadku obu kompletnych osełek wolińskich, okucia znalezionego w $1974 \mathrm{r}$. oraz osełki z Parchimia-Löddigsee elementy metalowe odlano z łatwo topliwych stopów. Uchwyt osełki z wykopu 6/1660 oraz okucie znalezione w 1974 r. powstały z prawie czystej cyny - temperatura topnienia tego metalu wynosi $231,9^{\circ} \mathrm{C}$. W przypadku zwieńczenia osełki odkrytej w wolińskim porcie, ze względu na dużą domieszkę ołowiu, była ona jeszcze niższa - około $190-210^{\circ} \mathrm{C}^{17}$. Zdjęcia rentgenowskie obu kompletnych osełek wolińskich nie wykazały istnienia na ich zakończeniach otworów, do których metalowe okucia mogły być przytwierdzane (ryc. 8). Trzeba zatem założyć, że osełkę wciskano bezpośrednio w formę wypełnioną roztopionym metalem- albo montowano na zimno na wcisk, stosując dodatkowo jakieś lepiszcze. Przez analogię za formę do odlewania okuć osełek uznać można zabytek znaleziony w 1975 r. na Starym Mieście w Wolinie, kształt negatywu odpowiada bowiem okuciu z wykopu 6/1660.

W tym kontekście nie do końca jasne jest przeznaczenie formy z negatywami twarzy znalezionej w Szczecinie. Otto Kunkel (1931, s. 97, Taf. 107) przypuszczał, że służyła ona do odlewania haczyków na ryby i ciężarków do sieci. Według Władysława Filipowiaka (1982, s. 116, Abb. 8; 1993, s. 30, ryc. 14) produkowano w niej dzwoneczki, które mogły być wykorzystywane w ceremoniach kultowych. Władysław Duczko (2000, s. 25), a za nim B. Stanisławski (2013, s. 165, ryc. 11.e) uznali, że podobnie jak forma wolińska okaz ze Szczecina służył do odlewania zawieszek do osełek. Każda $\mathrm{z}$ tych hipotez ma w sobie potencjał. Ciężarki do sieci z przedstawieniem ludzkich twarzy nie są jak dotychczas znane, trudno też wskazać powód tworzenia tak wyrafinowanych przedmiotów tego typu. Z Debryshire w środkowej Anglii pochodzi jednak, datowany na VII-VIII w., brązowy sześcian o wadze 10,2 g, zdobiony ludzkimi twarzami, który zinterpretowano jako odważnik lub przeciwwagę bezmianu (por. Mills 2012, s. 84). Hipoteza o dzwoneczkach także nie jest pozbawiona podstaw, zwłaszcza że wygląd negatywów sugeruje, iż odlewane $\mathrm{w}$ tej formie przedmioty miały kształt kulisty. Z obszaru zakarpackiego pochodzi cała seria kulistych dzwoneczków wykonanych z żelaza i stopów miedzi zdobionych wizerunkiem twarzy, tyle że dwóch, a nie czterech. Okazy te znajdowano na ogół w grobach kobiet i dzieci, datowanych na VII-VIII wiek. W ich wnętrzach umieszczono kamyki lub ziarenka, a dźwięk tych naszytych na strój lub zawieszonych przy pasie dzwoneczków/grzechotek pełnił funkcję apo-

17 Wykorzystywany współcześnie w przemyśle stop Sn50Pb50, zawierający w równych proporcjach cynę i ołów ma temperaturę topnienia $183-215^{\circ} \mathrm{C}$, a stop z większą zawartością cyny Sn60Pb40 - 183-190 $\mathrm{C}$ (dane za <http://www.innovator.com.pl/stopy_metali/stopy_lutownicze/> [dostęp 15 października 2017 r.]; por. też Miazga 2017, 101). 


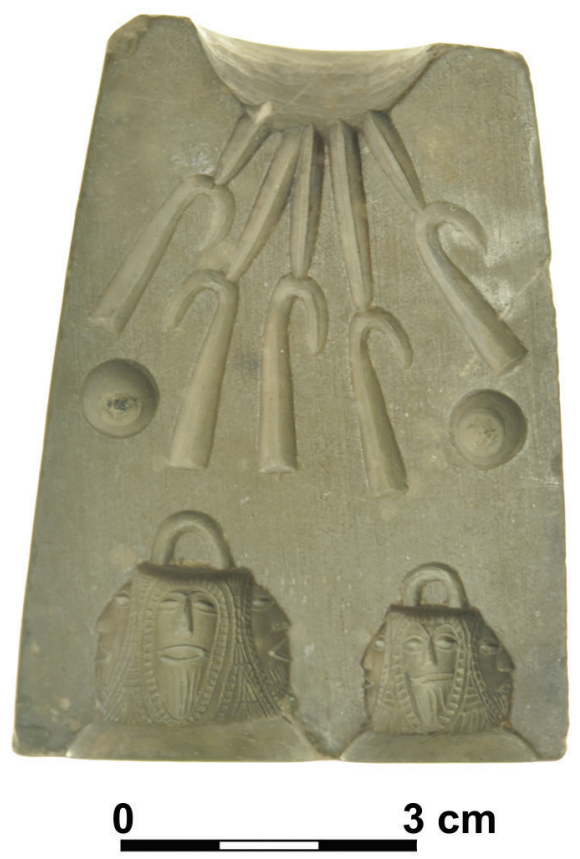

Ryc. 4. Szczecin. Forma do odlewania przedmiotów z wyobrażeniem czterotwarzowym (fot. A.B. Kowalska)

tropaiczną i miał odstraszać złe moce. Inspiracje do powstania tych amuletów pochodzić miały z obszaru śródziemnomorskiego (por. Rácz 2012, s. 426-429, 13. kép; Csuthy 2015, s. 220, obr. 9). Najsłabiej podbudowana jest moim zdaniem hipoteza o przeznaczeniu szczecińskiej formy do odlewania okuć osełek. W zasadzie jedynym punktem jej zamocowania jest przeświadczenie Władysława Duczki $(2000 \text {, s. } 25 ; 2014 \text {, s. } 146)^{18}$ o skandynawskim pochodzeniu przedstawień czterotwarzowych, takich jak Światowit, które miały być inspiracją dla twórców osełek. Dotykamy w tym miejscu kwestii kluczowej dla całości zagadnienia, czyli proweniencji osełek z okuciami. W artykule poświęconym obecności Skandynawów na południowych wybrzeżach Morza Bałtyckiego W. Duczko napisał, że „Znaleziska z Wolina i Szczecina w postaci metalowych uchwytów do zawieszek osełkowych, zdobionych czterema twarzami, dają świadectwo religijnych pojęć skandynawskich, żywych na zachodnim Pomorzu (ryc. 1c). Osełki tego typu znane są z Birki w środkowej Szwecji, a ich forma jest bardzo zbliżona do formy uchwytu małego

${ }^{18}$ Zwolennikiem hipotezy W. Duczki jest Błażej Stanisławski (2013, s. 165, ryc. 39.b), który bez bliższych wyjaśnień zaliczył formę i zawieszkę do osełki z Wolina do wyrobów pochodzenia skandynawskiego. 

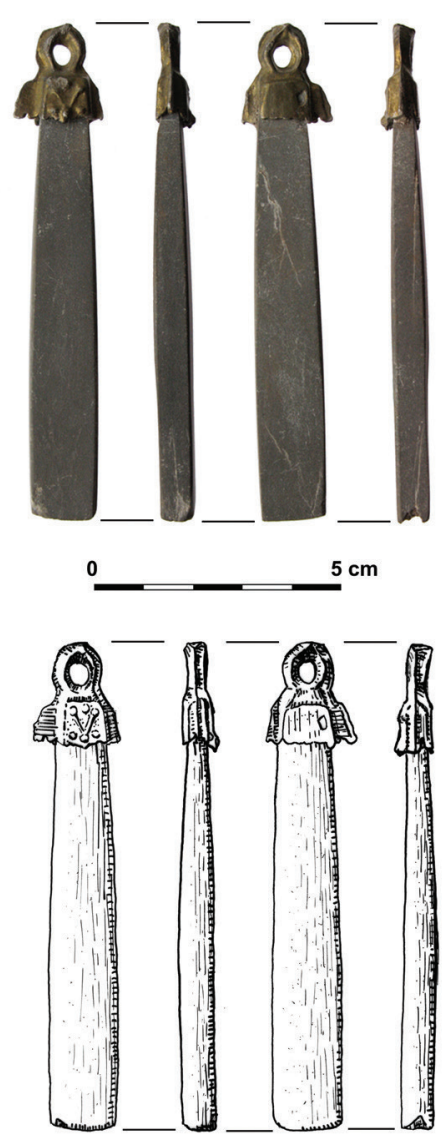

Ryc. 5. Wolin. Osełka nr inw. W3/2012/777/O (rys. K. Zielińska, fot. A. Janowski)

Światowita z Wolina" (Duczko 2000, s. 25-26). Krytyczna analiza tego krótkiego fragmentu tekstu pozwala wskazać kilka istotnych nieścisłości. Po pierwsze z niewiadomych przyczyn Autor zmultiplikował zabytki - w Szczecinie nie znaleziono metalowego uchwytu do osełki, a jedynie wspomnianą wcześniej formę (chyba jednak do dzwoneczków - AJ). Po drugie na żadnej z osełek wolińskich nie ma przedstawienia czterech twarzy. Nawet dając upust wyobraźni na okuciu odkrytym w 1974 r., dostrzec można ich zaledwie trzy, a na osełce z wykopu 6/1660 raptem dwie. Kolejne zdanie także wprowadza w błąd. Informacja, iż „Osełki tego typu znane są z Birki w środkowej Szwecji" nie jest prawdziwa(!), chyba, że zwrot „tego typu” odnosi się jedynie do surowca, czyli fyllitu, a nie faktu obecności metalowego okucia. Zdanie to jest zresztą tak złożone, że może także chodzić 


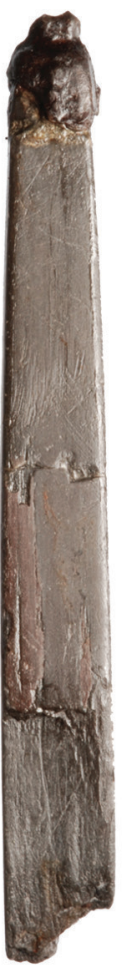

0

$5 \mathrm{~cm}$

Ryc. 6. Giecz. Osełka z metalowym uchwytem (fot. M. Jóźwikowska)

o formę jako taką, czyli wydłużony prostopadłościan, ale przecież taki kształt ma większość osełek. Dotychczasowe badania w Birce nie dostarczyły przedmiotów zdobionych wielogłowymi przedstawieniami, a na terenie całej Szwecji wskazać można co najwyżej dwa lub trzy takie zabytki ${ }^{19}$, a poza nią niewiele więcej. Problem ten nie jest obcy także W. Duczce, który w dalszej części artykułu pisze, iż „nieco później zapoznamy się ze szwedzkimi, datowanymi na $\mathrm{X}$ wiek znaleziskami przedmiotów z czterema głowami” (Duczko 2000, 26), po czym omawia jedyny w miarę kompletny szwedzki zabytek tego typu, czyli kościaną rękojeść z Lunby oraz dwugłowe dziś (uszkodzone?) przedstawienie na rękojeści z Väsby

${ }_{19}$ Bardzo serdecznie dziękuję Pani dr Charlocie Hedenstiernie-Jonson z Narodowego Muzeum Historycznego w Sztokholmie za potwierdzenie moich przypuszczeń co do braku tego typu przedstawień w sztuce skandynawskiej, a wśród przedmiotów z Birki w szczególności. 

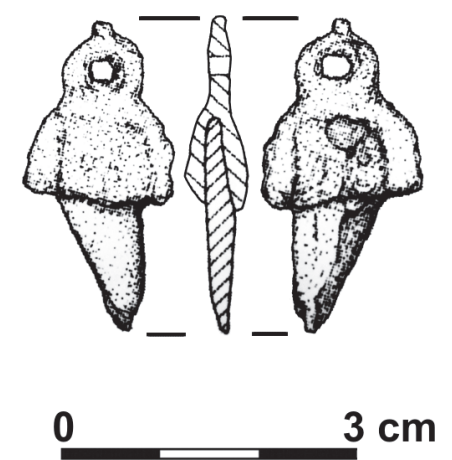

Ryc. 7. Parchim-Löddigsee. Osełka z metalowym uchwytem (Paddenberg 2012, Taf. 39.3934)

(por. Duczko 2000, s. 38, ryc. 12$)^{20}$. Hipoteza o północnym pochodzeniu tych wielogłowych przedstawień jest zastanawiająca, zwłaszcza iż jak sam pisze, to drugie znalezisko „można by uznać, dzięki rodzajowi dekoracji, za produkt woliński” (Duczko 2000, s. 39)(!). Nawet Jan Peder Lamm (1987, s. 225), którego tekst poświęcony kultowi wielogłowych bóstw został przez W. Duczkę przywołany, dość wyraźnie zaznaczył, że choć trzy- i czterotwarzowe wyobrażenia znane są ze Skandynawii, to bóstwa czterotwarzowe zostały zapożyczone od Słowian, natomiast trzytwarzowe znane są z mitologii nordyjskiej i mają powiązania z obszarami anglosaskimi ${ }^{21}$, zwłaszcza kulturą celtycką. Taki porządek rzeczy podkreślają też jednoznacznie wszyscy piszący później autorzy (por. m.in. Helmbrecht 2011, s. 222-223; Kajkowski, Szczepanik 2013; Szczepanik 2013; Gardeła 2014, s. 94-98).

Moim zdaniem trudno na podstawie jednego kompletnego i jednego uszkodzonego (?) wyobrażenia, przy całkowitym braku przekazów źródłowych o czterogłowych bóstwach obronić hipotezę o skandynawskim ich pochodzeniu. Równie trudno wykazać północną proweniencję osełek z okuciami. Kwerenda przeprowadzona w literaturze doprowadziła do zidentyfikowania niewielu takich zabytków.

${ }^{20}$ Do tej krótkiej listy można dołożyć jeszcze nieuwzględnioną przez W. Duczkę brązową szpilę z Bodin w Norwegii zdobioną na trzpieniu motywem czterech twarzy (por. Helmbrecht 2011, s. 222, Abb. 68.c).

${ }^{21}$ Najbardziej chyba znane wyobrażenie znajduje się na tzw. „,berle” z kurhanu nr 1 w Sutton Hoo we wschodniej Anglii. Ten odkryty w 1939 r. symboliczny grób (kenotaf) łodziowy z końca VI-początku VII w. zawierał cały szereg niezwykłych przedmiotów. Wśród nich był też osełkokształtny przedmiot z szarogłazu zwieńczony na obu końcach ozdobnymi metalowymi okuciami. Biorąc pod uwagę wymiary zabytku: całość ma $82 \mathrm{~cm}$ długości (58,3 cm mierzy część kamienna) i waży ponad $3 \mathrm{~kg}$, trudno jednak uznać go za osełkę i badacze przypisują mu raczej rolę „,berła”. W kontekście omawianych zagadnień istotne jest jednak to, że w górnej i dolnej części kamiennego elementu o wrzecionowatym kształcie wyrzeźbiono po cztery migdałowate wyobrażenia ludzkich twarzy (por. Mortimer, Pollington 2013; 2015, w tych pracach wyczerpująco starsza literatura). 


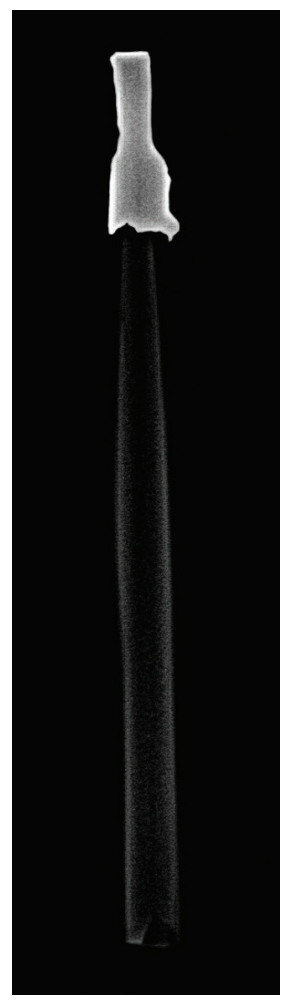

Ryc. 8. Wolin. Zdjęcie rentgenowskie osełka nr inw. W3/2012/777/O

Z duńskiego Haithabu pochodzi tylko jedna osełka fyllitowa zwieńczona okuciem zbliżonym do wolińskiego (ryc. 9). Wykonany z bliżej nieokreślonego metalu element wyrysowany został jako okrągły w przekroju (por. Resi 1990, s. 101, Taf. 10.2; Schietzel 2014, s. 233). Na publikowanych zdjęciach wygląda on jednak na bardzo skorodowany. Z Haithabu pochodzi także okucie w kształcie głowy zwierzęcia trzymającego w zębach obręcz. Brak informacji o surowcu i wymiarach przedmiotu, ale został on zinterpretowany jako zawieszka do osełki (por. Schietzel 2014, s. 233). Przyporządkowanie takie wzbudza moje wątpliwości. Przedmiot ten formą bliższy jest bowiem zakończeniom łańcuchów. Łańcuchy to elementy stroju właściwie nieznane na ziemiach słowiańskich, popularne natomiast $\mathrm{w}$ Skandynawii (por. Kóčka-Krenz 1993, s. 109-111). W młodszych fazach okresu wikińskiego, zwłaszcza w początkach XI w., zakończeniom nadawano ozdobny zoomorficzny kształt (por. Kóčka-Krenz 1983, s. 152). Doskonałym przykładem analogii z ziem polskich jest okaz z depozytu srebrnego odkrytego w 1856 r. w Borucinie na Kujawach.

Kilka kolejnych osełek z metalowymi uchwytami odkryto na Wyspach Brytyjskich. Najbliższy omawianym jest okaz z Llanbedrgoch w Walii, datowany na 

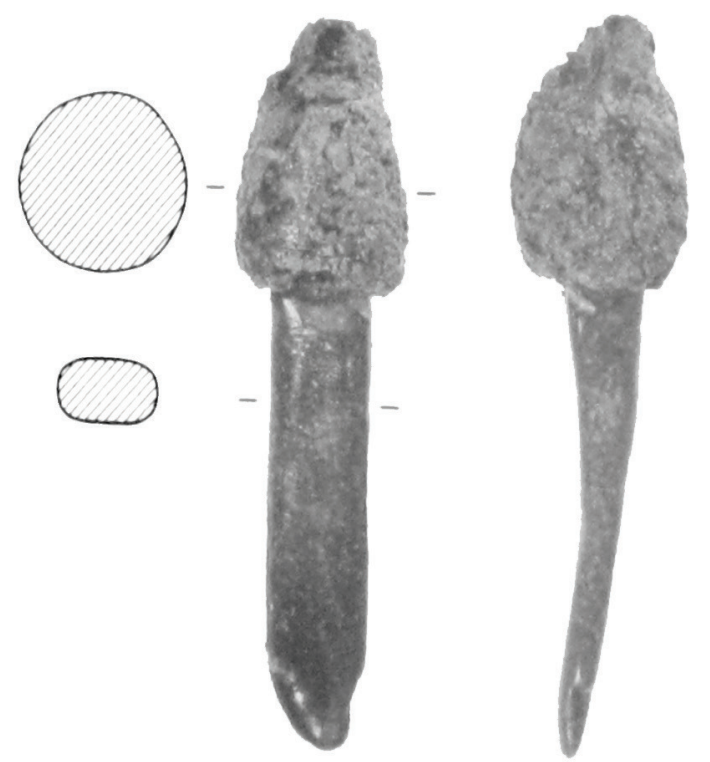

Ryc. 9. Haithabu. Osełka z metalowym uchwytem (wg Resi 1990, taf. 10.2)

IX-początek X wieku. Ten stosunkowo duży przedmiot ma długość $267 \mathrm{~mm}$, kwadratowy przekrój i wykonany został z drobnoziarnistego piaskowca. Oba jego końce są zaokrąglone, a na jednym $\mathrm{z}$ nich umieszczono brązowe posrebrzane okucie w kształcie stożkowatego hełmu z nosalem, zwieńczone kolistym uszkiem. Nosal widoczny jest jedynie $\mathrm{z}$ trzech boków osełki, a okucie przymocowano nitem osadzonym w nawierconym uprzednio otworze (Redknap 2004, s. 170, Fig. 14; https:// saesferd.wordpress.com/2009/10/26/sutton-hoo-sceptre/). Kolejny przykład pochodzi z Irlandii. W bliżej nieokreślonym miejscu znaleziono osełkę z łupku norweskiego o długości $93 \mathrm{~mm}$ i szerokości $14 \mathrm{~mm}$, z okuciem umieszczonym na grubszym końcu. Wykonany ze srebrzystego metalu element nie posiada uszka, zdobiony jest na powierzchni rytym ornamentem, a jego podstawa jest ukształtowana w formie czterech wydłużonych trójkątów, po jednym z każdego boku. Okucie zamocowano za pomocą nitów umieszczonych w szczytach trójkątów. Przedmiot datowany jest na IX-X w. (Ryan 1992, Pl. 7; Kleingärtner, Williams 2013, s. 51, fig. 32). Według Marka Redknapa (2004, s. 170) inne osełki tego typu znaleziono także w Newtownlow, Co. Westmeath w Irlandii, oraz w grobie z IX-X w. na cmentarzysku w Carlisle Cathedral w Anglii. Rzut oka do przywołanych przez tego autora prac wystarczy, aby zorientować się, że owa identyczność typów dotyczy istnienia zawieszki jako takiej, ale już nie jej kształtu i sposobu mocowania. W obu przypadkach jest to jedynie przynitowany pasek blachy z uszkiem. Podobne roz- 

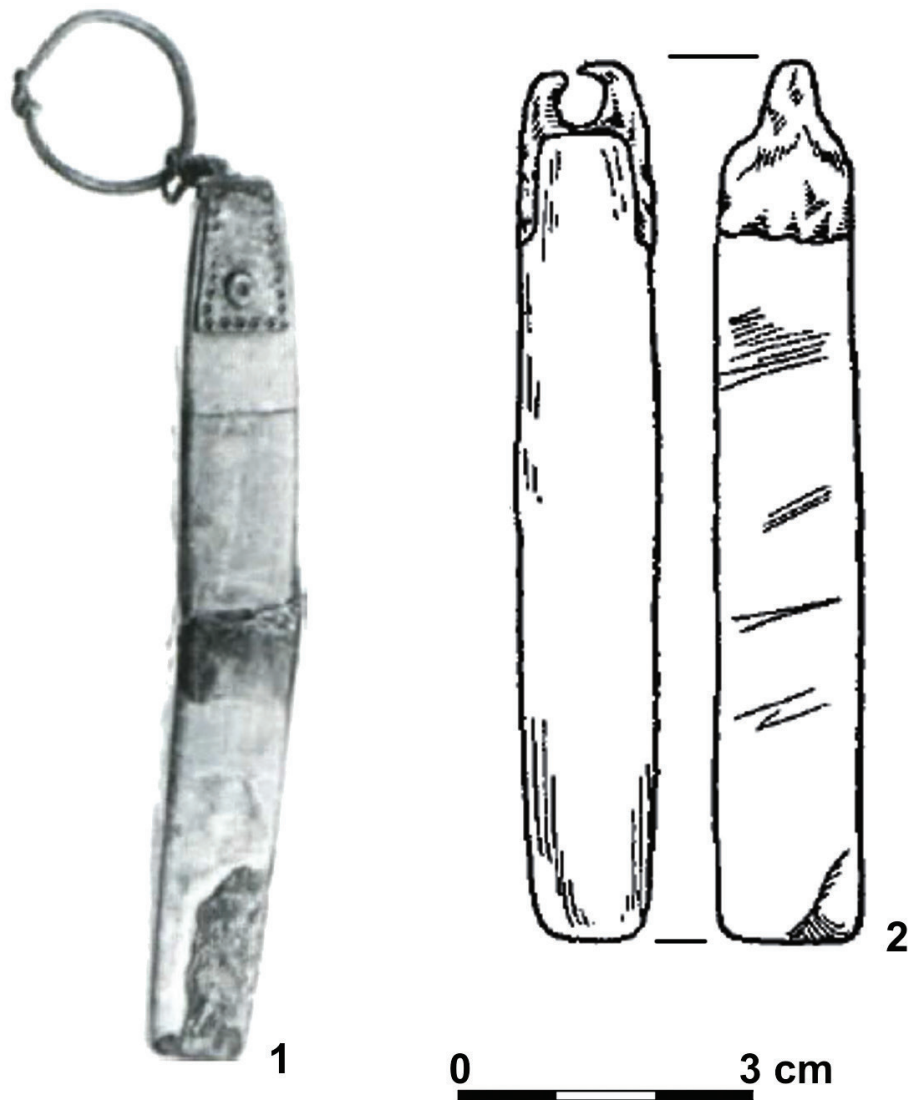

Ryc. 10. Czernichów. Osełki z okuciami: 1 - Czarna Mogiła (wg Put iz Varâg 1996, 78, nr 664), 2 - z kurhanu nr 15 (wg Bliefel'd 1965, tabl. II.6)

wiązania zastosowano m.in. w osełkach z Haithabu i Czernichowa. W pierwszym przypadku trapezowate pozłacane okucia z blachy przymocowano dwoma nitami (Resi 1990, s. 101, Taf. 10.1; Schietzel 2014, s. 233). Można podejrzewać, że osadzono je w przygotowanych wcześniej otworach. W Haithabu znaleziono 13 osełek z dwoma wywierconymi w niewielkiej odległości od siebie otworami (por. Resi 1990, Abb. 17) i niewykluczone, że są to okazy tego typu, pozbawione jedynie okuć.

W Czernichowie znaleziono dwie osełki zaopatrzone w okucia. Pierwszą odkryto w trakcie badań tzw. Czarnej Mogiły w latach 1872-1873. W tym datowanym na około 960 r. kurhanie złożono spalone ciała trzech osób, które na podstawie inwentarza zidentyfikowano jako mężczyznę, kobietę i dziecko. Osełkę o długości $90 \mathrm{~mm}, \mathrm{z}$ okuciem z brązu (ryc. 10.1) znaleziono wraz z dwoma innymi, niepo- 
siadającymi jednak metalowych elementów, w zachodniej części stosu pogrzebowego (Samokvasov 1916, s. 22, ris. 27, Nr 3319; Rybakov 1949, ris. 16; Put' iz Varâg 1996, s. 78, nr 664). W tym przypadku okucie ma formę zbliżoną do tych z Haithabu, ale zamocowane jest pojedynczym nitem.

Drugi egzemplarz z Czernichowa znaleziono w 1952 r. na cmentarzysku w północnej części miasta. Osełkę z różowego łupku o długości około $90 \mathrm{~mm}$ zaopatrzoną w uchwyt wykonany $\mathrm{z}$ brązu (ryc. 10.2) odkryto w południowej partii stosu pogrzebowego kurhanu nr 15 . Złożono $\mathrm{w}$ nim szczątki mężczyzny wraz z wierzchowcem ${ }^{22}$. Grób ten datowany jest na X w. (Bliefel'd 1965, s. 114-120, Tabl. II.6). Dostępne ryciny nie dają niestety klarownej odpowiedzi na sposób mocowania okucia.

Zaprezentowany przegląd znalezisk dość wyraźnie, jak sądzę, ukazuje, że w świecie nordyckim osełki zaopatrzone w metalowe uchwyty/zawieszki nie należały do przedmiotów powszechnych. Brak zatem moim zdaniem podstaw, by to Skandynawom przypisywać ich wytwarzanie. Wręcz przeciwnie, najwięcej znaleziono ich na obszarach zamieszkiwanych przez Słowian, stąd pochodzi też jedyna ewentualna forma do odlewania metalowych elementów. Wylansowana przez Władysława Duczkę hipoteza o ich skandynawskim pochodzeniu jest moim zdaniem pozbawiona podstaw, podobnie jak upatrywanie w nich analogii do Światowita. $\mathrm{Na}$ żadnym ze znanych dziś okuć osełek nie ma czterotwarzowego przedstawienia, a osełki przypominają znalezioną w Wolinie drewnianą figurkę tego „bóstwa” jedynie swoim prostopadłościennym kształtem. Zabytki te stanowią bez wątpienia wytwór słowiański i, o czym jestem przekonany, miejscowy, woliński fenomen.

Odrębne zagadnienie stanowi problem funkcji tych przedmiotów. Czy istotnie były to osełki? Niewielkie ślady zużycia pozwalają zdaniem M. Redknapa (2004, s. 170) interpretować okazy walijskie i irlandzkie bardziej jako symbol statusu niż narzędzie codziennej pracy. Według tego badacza osełki służyły do ceremonialnego ostrzenia mieczy i jako symbol władzy i autorytetu. Koncepcja ta choć nie jest nowa (por. Mitchell 1985), zasługuje moim zdaniem na poważne rozpatrzenie. Nadmienić należy $\mathrm{w}$ tym miejscu, że „osełkopodobne” przedmioty z różnego kształtu okuciami (niekiedy zoomorficznymi) z otworem do zawieszania znamy z obszaru Bliskiego Wschodu co najmniej od początku 1 tysiąclecia p.n.e. Co interesujące, występują one na tym obszarze nie tylko jako zabytki kultury materialnej, ale widnieją w tamtejszej ikonografii - zamocowane za pasem na przedstawieniach władców asyryjskich. Ich interpretacja funkcjonalna jest zbliżona do tej zaproponowanej przez M. Redknapa - symbole statusu lub kamienie probiercze (por. Ježek 2017, s. 37-44, Fig. 6, 10-1).

Obie wolińskie osełki mają regularny kształt i gładkie powierzchnie. Forma ta nie jest wynikiem zużycia, ale efektem starannego opracowania. Czy sens miałoby precyzyjne nadawanie im określonej formy, gdyby miały zostać zniszczone w wy-

${ }^{22} \mathrm{~W}$ grobie złożono też przypuszczalnie spalone ciało kobiety. 
niku codziennej eksploatacji? Jeżeli przyjąć, że nie wykorzystywano ich do ostrzenia i czynność ta wykonywana była nimi jedynie okazjonalnie, to istotnie nazywać należy je raczej, jak czyni to W. Duczko, zawieszkami osełkowymi, a nie osełkami.

\section{BIBLIOGRAFIA}

Blifel'd D.I. 1965, Drevn'orus 'kij mogil'nik v Černigovi, „Arheologiâ” 18, s. 105-138.

Csuthy A. 2015, Dekorativne kovania konského postroja z neskorého stupňa obdobia avarského kaganátu, w: Hradiská - Svedkovia dávnych čias. Zbornik odborných príspevkov o hradiskách a ich obyvatel'och, Dolná Mariková, s. 217-229.

Duczko W. 2000, Obecność skandynawska na Pomorzu i stowiańska w Skandynawii we wczesnym średniowieczu, w: L. Leciejewicz, M. Rębkowski (red.), Salsa Cholbergiensis. Kołobrzeg w średniowieczu, Kołobrzeg, s. 23-44.

- 2014, Viking-Age Wolin (Wollin) in the Norse Context of the Southern Coast of the Baltic Sea, „Scripta Islandica” 65, s. 143-152.

Filipowiak W. 1982, Der Götzentempel von Wolin, Kult und Magie, w: H. Kaufman (red.), Beiträge zur Ur- und Frühgeschichte, teil 2. Arbeits- und Forschungsberichte zur Sachsischen Bodendenkmalpflege, Beiheft, 17, Berlin, s. 109-123.

- 1986, Wolin-Vineta. Wykopaliska zatopionego miasta, Rostock-Stralsund.

- 1991, Wolin-Jomsborg. En Vikingtids-Handelsby i Polen, Roskilde.

- 1993, Stowiańskie wierzenia pogańskie u ujścia Odry, w: M. Kwapiński, H. Paner (red.), Wierzenia przedchrześcijańskie na ziemiach polskich, Gdańsk, s. 19-46.

Gardeła L. 2014, Scandinavian Amulets in Viking Age Poland, Rzeszów.

Helmbrecht M. 2011, Wirkmächtige Kommunikationsmedien: Menschenbilder der Vendel- und Wikingerzeit und ihre Kontexte, „Acta Archaeologica Lundensia”, Series Prima in $4^{\circ}, 30$, Lund.

Janowski A. 2013, Harbours of early medieval Wolin in the light of recent research, w: M. Bogucki, M. Rębkowski (red.), Economies, Monetisation and Society in the West Slavic Lands 800-1200 AD, Wolińskie Spotkania Mediewistyczne 2, Szczecin, s. 45-58.

- 2014, W wolińskim porcie.../In Wolin's port..., Wolin.

Ježek M. 2017, Archaeology of Touchstones. An introduction based on finds from Birka, Sweden, Leiden.

Kajkowski K., Szczepanik P. 2013, The multi-faced so-called miniature idols from the Baltic Sea area, „Studia Mythologica Slavica” 16, s. 55-68.

Kara M. 2006, W kwestii pochodzenia wczesnośredniowiecznych osetek z fyllitu odkrytych na ziemiach Polski pótnocno-zachodniej-głos w dyskusji, w: M. Dworaczyk, A.B. Kowalska, S. Moździoch, M. Rębkowski (red.), Świat Stowian wczesnego średniowiecza, Szczecin-Wrocław, s. 395-404.

Kleingärtner S., Williams G. 2013, Contacts and exchange, w: G. Williams, P. Pentz, M. Wemhoff (red.), Viking, Copenhagen, s. 30-69.

Kóčka-Krenz H. 1983, Złotnictwo skandynawskie IX-XI wieku, Poznań.

- 1993, Biżuteria pótnocno-zachodniosłowiańska we wczesnym średniowieczu, Poznań.

Kowalówka A. 2012, 181. Forma odlewnicza, w: K. Kowalski, D. Kozłowska-Skoczka (red.), Zaginione-ocalone. Szczecińska kolekcja starożytności pomorskich, Szczecin, s. 362.

Krysztofiak T. 2016, Ośrodek grodowy w Gieczu w okresie przed- $i$ wczesnopaństwowym, w: M. Kara, T. Krysztofiak, A.W. Wyrwa (red.), Gród piastowski w Gieczu. Geneza - funkcja - kontekst, Poznań, s. $115-154$.

Kunkel O. 1931, Pommersche Urgeschichte in Bildern, Stettin.

Lamm J.P. 1987, On the cult of multiple-headed gods in England and in the Baltic Area, „Przegląd Archeologiczny" 34, s. 219-231.

Lisowska E. 2013, Wydobycie i dystrybucja surowców kamiennych we wczesnym średniowieczu na Dolnym Ślasku, Wrocław. 
Łosiński W. 1997, Rola kontaktów ze Skandynawia w dziejach gospodarczych Stowian Nadbattyckich, „Przegląd Archeologiczny”, 45, s. 73-86.

Miazga B. 2017, Zabytek archeologiczny jako źródło informacji o przeszłości. Badania specjalistyczne śladów produkcji użytkowania i depozycji artefaktów, Wrocław.

Mills N. 2012, Saxon and Viking Artefacts, London.

Mitchell C. 1985, The Whetstone as Symbol of Authority in Old English and Old Norse, „Scandinavian Studies" 57(1), s. 1-31.

Mortimer P., Pollington S. 2013, Remaking the Sutton Hoo Stone. The Ansell-Roper Replica and its Context, Downham.

- 2015, The Sutton Hoo Stone: Whetstone, sceptre or something else?, w: L. Gardeła, K. Kajkowski (red.), Limbs, bones and reopened graves in past societies, Bytów, s. 445-470.

Paddenberg D. 2012, Die Funde der jungslawischen Feuchtbodensiedlung von Parchim-Löddigsee, Kr. Parchim, Mecklenburg-Vorpommern, „Frühmittelalterliche Archäologie zwischen Ostsee und Mittelmeer" 3, Wiesbaden.

Put' iz Varâg 1996, Put' iz Varâg v Greki i iz Grek... Katalog vystavki, Moskva.

Rácz Z. 2012, Emberalakos kistárgyak az avar korból, w: T. Vida (red.), Thesaurus Avarorum. Régészeti tanulmányok Garam Éva tiszteletére, Budapest, s. 409-436.

Redknap M. 2004, Viking-age settlements in Wales and the evidence from Llanbedrgoch, w: J. Hines, A. Lane, M. Redknap (red.), Land, Sea and Home, Leeds, s. 139-176.

Resi H.G. 1990, Die Wetz- und Schleisteine aus Haithabu, w: H.G. Resi, Die Wetz- und Schleifsteine aus Haithabu, Berichte über die Ausgrabungen in Haithabu 28, Neumünster, s. 9-134.

Ruchhöft F. 2017, Zvarin - Schwerin. Von der Inselburg zur Residenz, Schwerin.

Ryan M. 1992, The Sutton Hoo ship burial and Ireland: some Celtic perspective, w: R. Farrell, C. Neuman de Vegvar (red.), Sutton Hoo. Fifty years after, American Early Medieval Studies 2, Oxford, s. 83-116.

Rybakov B.A. 1949, Drevnosti Černigova, w: N.N. Voronin (red.), Materialy i issledovaniâ po arheologii drevnerusskih gorodov 1, Materialy i issledovaniâ po arheologii SSSR 11, Moskva-Leningrad, s. 7-93.

Samokvasov D.A. 1916, Mogil’nyâ drevnosti Severânskoj Černigoŝiny, Moskva.

Schietzel K. 2014, Spurensuche Haithabu. Archäologische Spurensuche in der frühmittelalterlichen Ansiedlung Haithabu. Dokumentation und Chronik 1963-2013, Neumünster-Hamburg.

Stanisławski B. 2000a, Gussform, w: A. Wieczorek, H.-M. Hinz (red.), Europas Mitte um 1000. Katalog, Stuttgart, 92.

- 2000b, Hundekopfanhänger, w: A. Wieczorek, H.-M. Hinz (red.), Europas Mitte um 1000. Katalog, Stuttgart, s. 92.

- 2013, Jómswikingowie z Wolina-Jómsborga - studium archeologiczne przenikania kultury skandynawskiej na ziemie polskie, Wrocław.

Stanisławski B., Filipowiak W. 2013, Wolin wczesnośredniowieczny, cz. 1, Warszawa.

Szczepanik P. 2013, Wczesnośredniowieczne figurki wielotwarzowe z terenów basenu Morza Baltyckiego - dowód kontaktów międzykulturowych czy uniwersalny fenomen?, „Archaeologia Historica Polona” 21, s. 49-60.

Szydłowski M. 2011, Wstępna analiza kamiennych osetek z wczesnośredniowiecznego Wolina, w: M. Rębkowski (red.), Ekskluzywne życie-dostojny pochówek. W kręgu kultury elitarnej wieków średnich, Wolińskie Spotkania Mediewistyczne 1, Szczecin, s. 45-51.

- 2013, Possibility of identification of Scandinavian presence on the Polish territory in the light of petroarchaeological research, w: B. Stanisławski, S. Moździoch, P. Wiszewski (red.), Scandinavian Culture in Medieval Poland, Wrocław, s. 457-466. 